\title{
PENERAPAN METODE SQ3R MENINGKATKAN KEMAMPUAN MEMBACA PEMAHAMAN PADA SISWA SDN 002 TOAPAYA
}

\author{
Zasnimar \\ Guru SDN 002 Toapaya \\ Email: zasnimarsdn002@gmail.com
}

\begin{abstract}
In learning to read, it involves students to be active with teacher's guidance, so that the concepts on the subject can be understood, so as to improve students' reading skills. By improving reading skills through the use of SQ3R learning method, students are expected to be able to solve problems, make decisions, think critically, and think creatively so that students' learning outcomes can also be improved. The SQ3R method is expected that students can understand and remember the material in a longer / permanent period of time. The use of the SQ3R method in learning will feel more interesting so that it can increase motivation to understand a reading. In essence, reading is a physical and mental activity to find the meaning of writing, although in that activity there is a process of recognizing letters. Based on the two opinions above, the researcher agrees that reading involves many things including physical, namely the eyes, involving mental, namely thoughts, especially perception and memory. To achieve the goal of reading, it requires not only the ability to understand what is implied but also the skills to understand what is implied in a reading text.
\end{abstract}

\section{Keywords: SQ3R Method, Reading Ability, Comprehension}

\section{PENDAHULUAN}

Ada empat aspek keterampilam berbahasa, yaitu mendengarkan, berbicara, membaca, dan menulis. Pembelajaran keterampilan mendengarkan diarahkan pada kemampuan memahami penjelasan narasumber dan cerita rakyat secara lisan, dengan berkonsentrasi, memahami, dan memberikan respon pada informasi yang didengar. Pembelajaran keterampilan berbicara diarahkan pada kemampuan pengungkapkan pikiran, gagasan, pendapat, dan perasaan dengan menyampaikan sambutan, pesan, pengalaman, serta menceritakan hasil pengamatan, atau berwawancara. Pembelajaran keterampilan membaca diarahkan pada kemampuan memahami teks dengan membaca teks percakapan, membaca cepat 75 kata per-menit dan membaca puisi. Pembelajaran keterampilan menulis diarahkan pada kemampuan mengungkapkan pikiran, perasaan, informasi, dan pengalaman secara tertulis dalam bentuk karangan, surat undangan, dan dialog tertulis.

Dari empat keterampilan di atas, keterampilan membaca merupakan keterampilan penting dalam mengembangkan kemampuan berbahasa. Karena proses belajar yang efektif antara lain dilakukan melalui membaca. Masyarakat yang gemar membaca memperoleh pengetahuan dan wawasan baru yang akan semakin meningkatkan kecerdaasan sehingga mereka lebih mampu memjawab tantangan hidup pada masa-masa mendatang. Peranan guru dalam proses membaca antara lain menciptakan pengalaman yang memperkenalkan, memelihara, atau memperluas kemampuan siswa untuk memahami teks.

Dari penjelasan di atas perlu adanya metodemetode pembelajaran yang bervariasi untuk meningkatkan kemampuan membaca pemahaman. Untuk itu saya mengambil judul: "Penerapan Metode SQ3R Meningkatkan Kemampuan Membaca Pemahaman Pada Siswa SD Negeri 002 Toapaya". Dalam pembelajaran membaca pemahaman, siswa diarahkan agar mampu membaca teks percakapan dengan lafal dan intonasi yang tepat. Kompetensi yang dikembangkan dalam pembelajaran membaca pemahaman tertulis dalam indikator pembelajaran. Indikator tersebut adalah membaca teks percakapan dengan menggunakan lafal dan intonasi yang tepat, mencatat pokok-pokok isi percakapan, dan menulis rangkuman isi percakapan. Jadi, indikator tersebut merupakan standar pembelajaran membaca pemahaman yang harus dikuasai oleh siswa.

Permasalahan yang dialami siswa dalam pembelajaran membaca pemahaman perlu diatasi dan dicarikan jalan keluarnya. Salah satu alternatif pemecahannya yakni dengan menggunakan metode pembelajaran yang efektif dan fungsional. Metode pembelajaran bahasa adalah rencana 
pembelajaran bahasa yang mencakup pemilihan, penentuan, dan penyusunan secara sistematis bahan yang akan diajarkan kepada siswa. Pada pembelajaran membaca pemahaman, saya memilih metode SQ3R untuk menyelesaikan permasalahan dalam pembelajaran membaca pemahaman. Metode SQ3R adalah metode yang meliputi 5 unsur yaitu Survey atau meneliti, Question atau membuat pertanyaan-pertanyaan, Reading atau membaca, Recite atau memahami secara mendasar, Review atau membaca secara berulang-ulang.

Dari latar belakang masalah di atas dapat diidentifikasi beberapa permasalahan sebagai berikut : (1) Pada umumnya guru tidak mengajarkan teknik membaca dengan pemahaman; (2) Penerapan metode pemahaman membaca yang kurang untuk merangsang motivasi siswa untuk banyak membaca. (3) Sebagian siswa kurang mampu memahami teks dengan membacakan teks percakapan menggunakan lafal dan intonasi yang tepat; (4) Metode pembelajaran membaca pemahaman kurang bervariasi, dan (5) Siswa belum mengetahui tujuan dan manfaat membaca pemahaman.

Bahasa Indonesia mempunyai kedudukan sebagai bahasa nasional dan bahasa negara. Kedudukan bahasa Indonesia sebagai bahasa negara berfungsi sebagai bahasa pengantar di lembaga-lembaga pendidikan, sebagai pengembang kebudayaan, sebagai pengembang ilmu pengetahuan dan teknologi, serta sebagai alat perhubungan dalam kepentingan pemerintahan dan kenegaraan.

Menurut Ahmad Susanto (2013) "Belajar adalah suatu proses yang ditandai dengan adanya perubahan pada diri seseorang sebagai hasil dari pengalaman dan latihan". Pembelajaran menurut Hamalik (2013), "Pembelajaran adalah upaya mengorganisasi lingkungan untuk menciptakan kondisi belajar bagi peserta didik". Kurikulum nasional mata pelajaran bahasa Indonesia berorientasi pada hakikat pembelajaran bahasa Indonesia. Menurut tim pengembangan kurikulum (2001:8) "Hakikat pembelajaran bahasa yaitu belajar bahasa adalah belajar berkomunikasi". Dari ketiga pendapat di atas, maka peneliti menyimpulkan bahwa hakikat pembelajaran bahasa Indonesia adalah untuk mengarahkan supaya peserta didik dapat terampil berkomunikasi dalam bahasa Indonesia, baik itu secara lisan maupun tulisan, serta baik dalam situasi formal maupun informal. Selain terampil berkomunikasi, siswa diharapkan memiliki sikap apresiatif terhadap karya sastra bahasa Indonesia.
Membaca adalah sebuah keharusan bila kita ingin menguasai dunia. Dengan membaca, pandangan kita menjadi lebih terbuka terhadap halhal baru yang tidak kita ketahui sebelumnya. Masyarakat negara maju ditandai oleh telah berkembangnya budaya baca (Putri Kumala Dewi 2018:245). Bila sebelumnya membaca identik dengan buku, maka di zaman yang serba digital ini membaca tidak hanya terpaku pada membaca buku karena segala informasi terkini telah tersedia di dunia maya. Menurut Akhmad Slamet Harjasujana (2005) "Satu-satunya cara untuk menyerap berbagai informasi dalam berbagai media cetak dengan waktu yang relatif singkat yaitu dengan meningkatkan kecepatan membaca".

"Membaca pada hakikatnya adalah suatu yang rumit yang melibatkan banyak hal, tidak hanya sekadar melafalkan tulisan, tetapi juga melibatkan aktivitas visual, berpikir, psikolinguistik dan metakognitif" (Crawley dan Mountain dalam Farida Rahim, 2007:2). mengemukakan bahwa "Membaca pada hakikatnya adalah kegiatan fisik dan mental untuk menemukan makna dari tulisan, walaupun dalam kegiatan itu terjadi proses pengenalan huruf-huruf'. Berdasarkan kedua pendapat di atas, peneliti sependapat bahwa membaca melibatkan banyak hal diantaranya melibatkan fisik yaitu mata, melibatkan mental yaitu pikiran khususnya persepsi dan ingatan.

Menurut Muhammad Noer (2012:14) "Membaca cepat adalah suatu kegiatan merespon lambang-lambang cetak atau lambang tulis dengan pengertian yang cepat dan tepat". Menurut Burhan El Fanany (2012) "Membaca cepat adalah perpaduan kemampuan motorik (gerakan mata) atau kemampuan visual dengan kemampuan kognitif seseorang dalam membaca". Dari kedua pendapat di atas, peneliti menyimpulkan bahwa membaca cepat ialah perpaduan antara gerakan mata untuk merespon lambang tulis dengan pemahaman isi bacaan secara cepat.

Membaca hendaknya mempunyai tujuan, karena seseorang yang membaca dengan suatu tujuan, cenderung lebih memahami dibandingkan dengan orang yang tidak mempunyai tujuan. Menurut Albert dalam Harras (1997) tujuan utama membaca cepat ialah (1) Memperoleh kesan umum dari suatu buku, artikel atau tulisan singkat; (2) Menemukan hal tertentu dari suatu bahan bacaan; (3) Menemukan atau menempatkan bahan yang diperlukan dalam suatu bahan bacaan.

Dari pendapat di atas, peneliti menyimpulkan bahwa pada dasarnya membaca cepat mempunyai tujuan untuk memahami isi dan makna bacaan dalam waktu yang sesingkat mungkin. Untuk 
mencapai tujuan membaca tidak hanya diperlukan kemampuan memahami apa yang tersirat melainkan juga keterampilan memahami yang tersurat dalam sebuah teks bacaan. Membaca cepat merupakan faktor yang sangat penting dalam kehidupan, karena membaca cepat dapat menyerap berbagai informasi yang diperlukan dalam kehidupan sehari-hari.

Membaca buku, koran, majalah atau dari media yang lain dapat melatih otak untuk memusatkan pikiran. Otak diajak untuk memperhatikan kata demi kata yang ada pada teks, jika kehilangan beberapa kata saja akan sulit menangkap keseluruhan maksud dari kalimat yang ada. Kalimat-kalimat yang menarik akan merangsang saraf otak untuk bekerja dan mengamati hal menarik tersebut. Berikut ini beberapa manfaat membaca cepat menurut Yaneu Sulistiawati (2008:5-9).

Selain beberapa manfaat di atas, membaca juga menjadikan orang lebih pintar dan cerdas. Dewasa dalam hal pola dan cara berpikirnya. Menurut Aniatul Hidayah (2012:15) "Manfaat membaca yaitu kemampuan menangkap, menyerap dan menguasai informasi dengan cepat serta meningkatnya kemampuan kita dalam memahami isi bacaan". Deni Muhammad Danial (2008:40) juga mengemukakan bahwa "Membaca merupakan salah satu cara untuk memperbaiki dan meningkatkan keefektifan diri kita". Saat membaca pengetahuan akan semakin bertambah. Dengan demikian pemahaman terhadap masalah-masalah yang terjadi di kehidupan ini semakin meningkat.

Secara garis besar H.G. Tarigan (2008:12-13) menyatakan bahwa ada 2 aspek dalam membaca, yaitu: Keterampilan yang bersifat mekanis (mechanical skills) yang dapat dianggap berada pada urutan yang lebih rendah (lower order). Aspek ini mencakup: (1) Pengenalan bentuk huruf; (2) Pengenalan unsur-unsur linguistik (fonem/grafem, kata, frase, pola klausa, kalimat, dan lain-lain); (3) Pengenalan hubungan respondensi pola ejaan dan bunyi (kemampuan menyuarakan bahan tertulis atau "to bark at print"); (4) Kecepatan membaca ke taraf lambat

Keterampilan yang bersifat pemahaman (comperhension skills) yang dapat dianggap berada pada urutan yang lebih tinggi (higher order), aspek ini mencakup: (1) Memahami pengertian sederhana (leksikal, gramatikal, retorikal); (2) Memahami signifikansi atau makna (maksud dan tujuan pengarang, relevansi/keadaan kebudayaan dan reaksi pembaca); (3) Evaluasi atau penilaian (isi, bentuk); (4) Kecepatan membaca yang fleksibel, yang mudah disesuaikan dengan keadaan.

Berdasarkan kedua aspek membaca yang dikemukakan, peneliti menggunakan aspek yang bersifat pemahaman karena penelitian ini ditujukan untuk kelas tinggi yaitu kelas $\mathrm{V}$, dimana kelas $\mathrm{V}$ ini sudah lancar membaca dan bisa memahami maksud dan tujuan pengarang.

Kecepatan Efektif Membaca. Penanaman pengertian tentang pentingnya membaca cepat dan penanaman keterampilan membaca cepat perlu dilakukan sejak dini. Menurut Akhmad Slamet Harjasujana (1996:54) "Kecepatan membaca adalah kemampuan seseorang dalam menggerakkan mata secara cepat dan tepat pada saat membaca sehingga diperoleh rata-rata kecepatan baca berupa jumlah kata per menit". Kecepatan efektif membaca (KEM) menurut Soedarso (2010:14) dapat dirumuskan sebagai berikut:

\begin{tabular}{lll}
\hline Jumlah kata yang dibaca & x 60 & $\begin{array}{l}\text { jumlah } \\
\text { kpm (kata } \\
\text { Jumlah detik untuk membaca }\end{array}$ \\
\hline
\end{tabular}

Untuk menghitung jumlah kata dalam bacaan yaitu: jumlah kata perbaris bacaan $\mathrm{x}$ jumlah baris bacaan

\section{METODE PENELITIAN}

Menurut Ngalimun (2012:171) "SQ3R adalah strategi membaca yang dapat mengembangkan meta kognitif siswa, yaitu dengan menugaskan siswa untuk membaca bahan belajar secara seksama dan cermat". Menurut Soedarso (2010:59) "SQ3R merupakan proses membaca yang terdiri dari lima langkah yaitu survey, question, read, recite atau recall, review".

Sebelum membaca, selidiki bacaan untuk menenal bahan bacaan sebelum membacanya secara lengkap, salah satunya dengan melihat judul, halaman cover, daftar isi, kata pengantar atau rangkuman yang terdapat di belakang buku, untuk memperoleh gambaran umum dari apa yang akan dibaca.

Membuat pertanyaan yang berkaitan dengan bacaan dengan menggunakan kata siapa, apa, kapan, di mana, mengapa dan bagaimana. "Semakin kritis pertanyaan yang diberikan, maka semakin tinggi juga pemahaman terhadap bacaan" (Aniatul Hidayah 2012:87). Dengan membuat beberapa pertanyaan akan membuat pembaca ingin menemukan jawaban dan dapat memahami bacaan tersebut 
Membaca buku dengan memperhatikan teknik membaca. Membaca dapat menemukan jawaban atas pertanyaan-pertanyaan yang telah dibuat sebelumnya, guna memahami isi bacaan. Menurut Soedarso (2010:63) "Ada dua hal yang harus diperhatikan dalam membaca, yaitu: (1) jangan membuat catatan. (2) jangan membuat tanda-tanda seperti garis bawah pada kata maupun frase tertentu". Membuat catatan dan membuat tandatanda pada kata maupun frase tertentu akan memperlambat membaca.

Ketika membaca, pahami isi bacaan, simpan kata kuncinya dan mengingat kembali isi bacaan yang sudah dibaca.

Tahap terakhir yaitu mengulas materi yang telah dibaca dengan menelusuri kembali judul dan bagian-bagian penting lainnya dengan menemukan pokok-pokok penting yang perlu untuk diingat kembali. "Review adalah proses memeriksa kembali isi bacaan" Santoso dalam Aniatul Hidayah (2012:91). Jadi untuk memahami isi bacaan perlu diulang bagian-bagian yang dianggap penting.

\section{PEMBAHASAN PENELITIAN \\ Rasional, Pengertian, Tujuan dan Manfaat SQ3R}

Pengajaran dengan metode suatu tertentu, akan memberikan hasil yang lebih baik, apabila dibandingkan dengan pengajaran tanpa metode. metode membaca yang termasuk paling awal pengembangannya dan metode yang paling popular ialah metode SQ3R yang dikembangkan oleh robinson. Metode ini dirancang menurut jenjang yang memberi kemungkinan kepada para siswa untuk belajar secara sistematis dalam menghadapi berbagai bahan yang berupa buku teks atau tugas dengan bantuan teknik-teknik atau strategi-strategi membaca yang dianggap lebih efisien.

SQ3R adalah suatu metode studi yang mencakup lima tahap membaca,yakni:(survey, question, read, recite dan review) atau dapat kita artikan sebagai tahap-tahap mensurvei, meneliti, mengajukan pertanyaan, membaca, menceritakan kembali, dan meninjau ulang.

Metode SQ3R bertujuan untuk: (1) Membekali siswa/mahasiswa dengan suatu pendekatan yang sistematis terhadap jenis-jenis kenyataan membaca, dan (2) Meningkatkan proses belajar mengajar secara lebih mantap dan efisien untuk berbagai materi bacaan.

Tujuan pertama, mencerminkan bekal bagi keperluan peningkatan cara belajar yang efektif dan efisien untuk kepentingan siswa/mahasiswa yang bersangkutan. Dengan metode SQ3R diharapkan siswa/mahasiswa memperoleh keberhasilan dalam studi dan dalam kehidupan.

Tujuan kedua, metode SQ3R selain diarahkan kepada kepentingan pembaca sebagai pribadi, juga diarahkan kepada suatu metode pengajaran pembaca untuk kepentingan orang lain.

Metode SQ3R ini memberi kemungkinan kepada pembacanya untuk menentukan apakah materi yang dihadapinya itu sesuai dengan keperluannya atau tidak. Metode SQ3R memberi kesempatan kepada para pembaca untuk bersifat fleksibel. Pengaturan kecepatan membaca untuk setiap bagian bacaan tidaklah sama. Pembaca akan memperlambat tempo kecepatan membaca untuk hal-hal yang baru baginya, atau bagian-bagian tertentu yang sangat dibutuhkannya. Sebaliknya, dia akan menaikkan tempo kecepatan bacanya, jika bagian-bagian bacaan itu kurang relevan dengan kebutuhannya atau hal-hal yang sudah dikenalinya.

Manfaat lain, pembaca dibekali dengan suatu metode belajar yang sistematis. Dengan metode ini, pencapaian hasil belajar dengan efektif dan efisien akan terjamin, apabila dibandingkan dengan belajar tanpa metode.

\section{Deskripsi, Metode dan Prosedur SQ3R}

Bagaimana cara kita membaca buku? Bukankah biasanya kita atau mereka selalu membaca buku dari awal halaman hingga akhir. Secara urut dan runtut. Wah, kalau untuk membaca novel atau buku cerita hal ini sah-sah saja, bahkan memang seharusnya begitu bukan? Ada sebuah teknik yang bisa digunakan untuk memenuhi tujuan pemahaman yaitu dengan metode SQ3R.

SQ3R pada mulanya dikembangkan oleh seorang profesor yang bernama Francis Robinson dari Universitas Negeri Ohio pada tahun 1940. "Survey" di dalam metode SQ3R berarti mencari judul, sub-judul, gambar, grafik, atau keterangan tambahan dari sebuah buku atau teks. Disini termasuk mencari huruf bercetak tebal ataupun huruf bercetak miring. Fungsi "Survey" ini adalah supaya kita mendapatkan gambaran umum akan apa yang akan kita baca. Kita punya outline bacaan atau teks tersebut. "Question" berarti kita memunculkan berbagai pertanyaan di kepala kita setelah kita melakukan "Survey" tadi. Fungsi "Question" ini adalah supaya kita terfokus pada apa yang akan kita baca. Kita bisa memunculkan pertanyaan-pertanyaan agar kita bisa fokus pada materi bacaan atau teks.

"Read" berarti waktunya kita membaca dari awal hingga akhir. Dalam tahap ini pertanyaanpertanyaan yang kita munculkan semestinya 
terjawab setelah kita melakukan proses "Read" ini. Pada tahap ini kita berusaha menjawab pertanyaanpertanyaan yang tadi muncul pada saat fase $Q$ (Question) sembari terus membaca. Langkah berikutnya adalah resitasi.

Fungsinya untuk mengetahui pemahaman kita akan apa yang kita baca. Dengan kata lain mengkomunikasikannya dengan bahasa yang berbeda. Mengkomunikasikan di sini bukan berarti mengkomunikasikan dengan orang lain, tetapi mengkomunikasikan dengan diri kita sendiri. "Review" berarti mengingat kembali apa yang telah kita baca. Disini kita memutuskan apa-apa yang ingin penulis sampaikan. Hal-hal apa yang perlu di ingat. Apakah pertanyaan yang kita kemukakan telah terjawab sepenuhnya.

Apakah ada yang tidak kita pahami ataupun ada hal-hal yang tidak kita setujui dengan penulis. Fungsi "Review" ini adalah meningkatkan lagi pemahaman kita ke level yang lebih tinggi.

Metode SQ3R yakni suatu metode studi yang meliputi lima tahap kegiatan membaca yang terdiri dari: (1) survey (meneliti), (2) question (mengajukan pertanyaan), (3) read (membaca), (4) recite (menceritakan kembali), dan (5) review (mengulang kembali). $\mathrm{S}=$ Survey, artinya meninjau, meneliti, yakni membaca bagian-bagian permulaan buku, seperti: halaman judul, kata pengantar, daftar isi, judul dan sub-sub judul, dan lain-lain. Bagian-bagian tersebut dibaca dengan teknik baca layap (skimming), yaitu membaca dengan cepat untuk mengetahui gambaran isi buku atau bagian buku secara umum. Dengan demikian, dalam waktu yang relative singkat, pembaca akan segera dapat mengetahui apakah buku itu sesuai dengan tujuannya.

$\mathrm{Q}=$ Question (Pertanyaan). Sebelum memulai kegiatan membaca, hendaknya pembaca membuat rumusan-rumusan pertanyaan sebagai informasi focus. Rumusan-rumusan pertanyaan hendaknya merentang dari pertanyaan ingatan, pemahaman, aplikasi, analisis, sintesi, sampai ada evaluasi. Agar memudahkan Anda catatlah setiap butir pertanyaan tersebut supaya tidak lupa.

R 1 = Reading (membaca). Untuk menjawab pertanyaan-pertanyaan yang telah diruskan pada tahap 2, selanjutnya mulailah dengan kegiatan membaca. Anda tidak perlu membaca dengan kecepatan yang sama. Anda dapat menilai, apakah bagian bacaan itu perlu dibaca seluruhnya atau tidak, sambil membaca. Kadang-kadang untuk seksi tertentu, Anda cukup membaca kalimatkalimat topiknya saja, biasanya terdapat paa awal atau akhir paragraf. Untuk bagian-bagian tertentu yang Anda anggap relevan dengan tujuan Anda dan baca bagian-bagian yang baru dikenali, bacalah seluruhnya dengan pengaturan kecepatan baca yang tidak terlalu tinggi. Di samping itu, daya pikir dan daya nalar Anda harus dilibatkan di dalamnya.

R 2 = Recite (menceritakan kembali). Setelah Anda merasa yakin bahwa sejumlah pertanyaan yang Anda rumuskan sebelum membaca telah terpenuhi, cobalah berhenti sejenak. Renungkan kembali setap pertanyaan dan setiap jawaban yang telah Anda peroleh, tulislah kembalidalam buku catatan Anda. Beberapa hal yang perlu Anda perhatikan dalam membuat catatan pribadi itu ialah: Buatlah dengan kata-kata sendiri, Catatan singkat, padat dan jelas, serta mencakup hal-hal yang penting,

Lakukanlah kegiatan ini secara mandiri tidak berbarengan (misalnya mencatat sambil membaca)

R 3 = Review (meninjau kembali). Pada akhir setiap bab yang dibaca, bab sebelumnya perlu ditinjau kembali dan dihubungkan dengan rumusan isi bab yang baru diselesaikan. Lakukan kegiatan seperti ini, sampai seluruh bagian buku dapat diselesaikan. Yang Anda lakukan pada kegiatan seperti ini bukan kegiatan membaca ulang. Anda cukup melihat judul-judul dan subjudulnya, gambar-gambar, diagram-diagram, grafik-grafik, dan meninjau kembali pertanyaan-pertanyaan.

Jika Anda membaca suatu buku, tentu anda mempunyai tujuan tertentu sebelum anda melakukannya. Tujuan itu bermacam-macam tergantung pada keperluannya masing-masing. Kegiatan membaca itu kadang-kadang hanya mencari hiburan, sebagai pengisi waktu senggang saja, atau mungkin hanya sekedar untuk mencari informasi tertentu, dan mungkin pula untuk keperluan study. Pada makalah ini akan dibicarakan khusus hal-hal yang ada kaitannya dengan kegiatan membaca untuk keperluan studi. Tujuan membaca disini bukan hanya sekedar menemukan informasi tertentu, melainkan lebih jauh sampai pada pemahaman isi secara keseluruhan secara konferehensif (mendalam dan padat). Spache mengemukakan enam keterampilan dasar yang penting dalam keberhasilan membaca suatu buku. Kemampuan mensurvei bahan, untuk menentukan: (1) Hal-hal yang bersifat umum; (2) Ide pokok; (3) Pendekatan membaca yang tepat

Kemampuan untuk menghubung-hubungkan pengetahuan yang diperoleh melalui kegiatan mensurvei untuk, memilih teknik membaca yang tepat. Fleksibilitas kecepatan rata-rata membaca yang bervariasi sesuai dengan teknik membaca skimming, scanning membaca cepat, dan tipe-tipe membaca untuk keperluan studi. Kemampuan memahami grafik dan gambar-gambar ilustrasi 
secara efektif. Keterampilan menggunakan perpustakaan dan referensi dasar yang khas dilapangan. Keterampilan rata-rata kemampuan secara umum seperti dalam hal pemahaman kosakata.

\section{Pendekatan SQ3R dan Penerapan metode SQ3R}

Untuk kemudahan, saya akan menggunakan pendekatan SQ3R sebagai berikut Survey. Yakni proses persiapan membaca dengan cara melihat secara sekilas isi buku mulai dari judul utama, sub judul, cover buku bagian belakang yang menjelaskan secara ringkas topik yang dibahas, kata pengantar dari penulis, maupun daftar isi. Proses selanjutnya dari tahapan Survey adalah dengan membuka secara cepat halaman demi halaman dan memperhatikan bagian judul bab, sub judul bab, kata-kata khusus yang bercetak tebal atau miring, tabel, gambar sambil mencoba mendapatkan ide besar dari buku tersebut.

Survey yang sukses akan menghasilkan gambaran umum tentang isi buku sekaligus menciptakan minat yang kuat untuk memahaminya. Ini merupakan modal penting untuk membantu proses membaca cepat isi buku secara keseluruhan disamping memastikan tingkat pemahaman yang tinggi akan isi buku.

Question. Tahap ini dilakukan bersamaan dengan proses survey terutama ketika Anda mempelajari daftar isi serta mulai membaca sekilas halaman demi halaman secara cepat. Sambil Anda membaca judul bab, sub judul bab, kata-kata khusus bercetak tebal atau miring, tabel dan gambar maka pada saat yang sama Anda melakukan proses bertanya kepada diri sendiri.

Read. Setelah dua tahap di atas dilakukan, maka mulailah proses membaca secara keseluruhan dilakukan. Dengan adanya persiapan sebelum membaca, maka proses baca keseluruhan isi dapat dilakukan dengan kecepatan tinggi. Hal ini dibantu karena pembaca tersebut telah mengenali ide pokok yang disampaikan penulis, memahami strukturnya, maupun terminologi yang banyak dipakai. Proses pembacaan keseluruhan ini dapat dilakukan dengan break di tiap akhir bab untuk kemudian melakukan review atau dengan cara menyelesaikan dulu secara total.

Recite.Proses resitasi atau melakukan refleksi atas bahan bacaan dapat Anda lakukan segera setelah mengakhiri satu bab. Langkah ini dilakukan untuk menguji pemahaman atas apa yang telah dibaca. Proses ini dilakukan dengan menceritakan ulang pokok pikiran yang dibahas dalam buku tersebut dengan gaya bahasa Anda sendiri. Jika hal tersebut dapat dilakukan menunjukkan bahwa Anda memahami isi buku tersebut. Proses resitasi ini sangat bermanfaat terutama ketika membaca buku-buku teks perkuliahan yang wajib dikuasai. Proses ini tidak berusaha menghafal apa-apa yang Anda baca melainkan berusaha memahami dengan bahasa sendiri apa-apa yang telah dibaca.

Review. Ketika kita menyerap informasi, maka apa-apa yang dibaca akan masuk ke dalam memori jangka pendek. Proses review dilakukan setelah proses membaca selesai agar apa-apa yang dibaca tidak hanya masuk dalam memori jangka pendek melainkan masuk ke memori jangka panjang.

Dengan demikian, kapanpun Anda perlu mengingat kembali materi bacaan tersebut, tinggal melakukan proses pemanggilan dari memori jangka panjang. Proses review awal dilakukan segera setelah mengakhiri bahan bacaan. Hal ini dilakukan mirip dengan proses "Survey" di mana Anda membolak-balik halaman secara cepat sambil melakukan review singkat untuk memastikan apa-apa yang dibaca telah terpahami.

Proses review ini cukup menghabiskan waktu 5 menit saja dan akan bermanfaat sekali dalam jangka panjang terutama terkait pemahaman dan ingatan akan bahan bacaan. Jika Anda mengabaikan proses review ini, mungkin Anda masih dapat mengingat dengan baik isi bahan bacaan. Akan tetapi, dalam 24 jam pemahaman tersebut akan turun cukup banyak dan terjadi penurunan drastis setelah seminggu. Metode SQ3R bersifat praktis dan dapat diaplikasikan dalam berbagai pendekatan belajar.

Penerapan metode SQ3R. Dalam pembelajaran membaca melibatkan siswa untuk aktif dengan bimbingan guru, agar konsep yang ada pada pokok bahasan tersebut dapat dipahami, sehingga dapat meningkatkan keterampilan membaca siswa. Dengan peningkatan keterampilan membaca menggunakan metode pembelajaran SQ3R, diharapkan siswa mampu memecahkan masalah, mengambil keputusan, berfikir kritis, dan berfikir kreatif sehingga hasil belajar siswa dapat juga ditingkatkan. Metode SQ3R ini diharapkan siswa dapat memahami dan mengingat materi dalam jangka waktu yang lebih lama/bersifat permanen. Penggunaan metode SQ3R dalam pembelajaran akan terasa lebih menarik sehingga dapat meningkatkan motivasi untuk memahami suatu bacaan.

Kemampuan membaca pemahaman. Menurut Sadler menyatakan, membaca tidak hanya sekedar memasangkan bunyi dengan huruf atau belajar kata-kata, membaca melibatkan 
pemahaman, memahami apa yang dibaca, apa maknanya, apa yang diimplikasikan. Membaca pemahaman berkaitan erat dengan usaha memahami hal-hal penting dari apa yang dibacanya. Yang dimaksud membaca pemahaman atau komprehensi adalah kemampuan membaca untuk mengerti ide pokok, detail penting, dan seluruh pengertian. Pemahaman ini berkaitan erat dengan kemampuan mengingat bahan yang dibacanya.

Berdasarkan pengertian tersebut, ada tiga hal atau tiga elemen dalam membaca pemahaman, yaitu: (1) Pengetahuan dan pengalaman yang telah dimiliki tentang topic; (2) Menghubungkan pengetahuan dan pengalaman dengan teks yang akan dibaca; (3) Proses pemerolehan makna secara aktif sesuai dengan pandangan yang dimiliki.

Usaha efektif untuk memahami dan mengingat lebih lama dapat dilakukan dengan: (1)Mengorganisasikan bahan yang dibacanya dalam kaitan yang mudah dipahami; (2) Mengaitkan fakta yang satu dengan fakta yang lain.

\section{Pendekatan membaca pemahaman dengan SQ3R}

Membaca adalah kegiatan atau suatu aktivitas yang rumit atau kompleks, karena bergantung pada keterampilan berbahasa pelajar, dan pada tingkat penalarannya (Sri Utari Subyakto Nababan, 1993: 164). Di sisi lain, Suyatmi berpendapat bahwa membaca merupakan sekedar kegiatan yang menyuarakan lambang-lambang tertulis saja tanpa mempersoalkan apakah kalimat atau kata-kata yang dilisankan itu dipahami atau tidak.

Sejalan dengan dua pengertian di atas Yasir Burhan dalam Suyatmi membaca adalah arti sesungguhnya ialah perbuatan yang dilaksanakan berdasarkan kerjasama atas beberapa keterampilan, yaitu mengamati, memahami, dan memikirkan. Dapat disimpulkan bahwa membaca merupakan aktivitas untuk memahami ide atau gagasan yang tersurat maupun tersirat di dalam suatu bacaan yang melibatkan kerjasama beberapa komponen keterampilan berbahasa.

Membaca cepat adalah keterampilan membaca sekilas dengan mengkondisikan otak bekerja lebih cepat sehingga konsentrasi akan lebih membaik secara otomatis. Dalam hal ini kita dituntut untuk memusatkan konsentrasi kita dalam proses membaca guna mengefisiensikan waktu yang kita miliki dan juga energi yang kita keluarkan juga akan relatif lebih banyak. Sedangkan pernyataan yang kedua menyebutkan bahwa membaca cepat adalah perpaduan kemampuan motorik (gerakan mata) atau kemampuan visual dengan kemampuan kognitif seseorang dalam membaca. Membaca cepat merupakan perpaduan antara kecepatan membaca dengan pemahaman isi bacaan. Kecepatan membaca seseorang harus seiring dengan kecepatan memahami bahan bacaan yang telah dibaca. Dan pernyataan terakhir menyinggung keterampilan membaca yang menyebutkan bahwa kemampuan membaca merupakan keterampilan memilih isi bacaan yang harus dibaca sesuai dengan tujuan, yang ada relevansinya dengan pembaca tanpa membuang-buang waktu untuk menekuni bagian-bagian lain yang tidak diperlukan. Sehingga dapat disimpulkan bahwa dalam membaca diperlukan konsentrasi yang lebih ketika membaca dam juga diperlukan perpaduan kemampuan motorik dengan kemampuan kognitif serta diperlukan waktu yang relatif singkat guna memperoleh informasi yang ada dalam bacaan baik yang tersirat maupun tersurat.

Hal-hal tersebut di atas merupakan sejumlah pengertian yang pada akhirnya merujuk kepada pengertian membaca cepat. Kemampuan membaca cepat seseorang pada dasarnya memiliki hubungan terhadap kemampuan mengkritisi sebuah tulisan. Namun, perlu kita ketahui bahwa kemampuan mengkritisi sebuah tulisan tidak lepas dari latar belakang pendidikan maupun pengalaman seseorang dan ini berarti hal terkait membaca cepat atau kritis berkaitan dengan pendidikan, khususnya pendidikan bahasa. Dalam pengajarannya, selain memerlukan tulisan sebagai media dan bahan ajar tentunya juga memerlukan teknik atau metode yang tepat dalam pelaksanaannya.

\section{Proses Membaca Pemahaman dengan SQ3R.}

Survey. Survey atau prabaca adalah teknik untuk mengenal bahan sebelum membacanya secara lengkap, dilakukan untuk mengenal organisasi dan ikhtisar umum yang akan dibaca dengan maksud untuk (1) Mempercepat menangkap arti; (2) Mendapatkan abstrak; (3) Mengetahui ide-ide yang penting; (4) Melihat susunan (organisasi) bahan bacaan tersebut; (5) Mendapatkan minat perhatian yang seksama terhadap bacaan; (5) Memudahkan mengingat lebih banyak dan memahami lebih mudah.

Question. (1) Ajukan pertanyaan sebanyakbanyaknya tentang isi bacaan itu; (2) Dengan adanya berbagai pertanyaan itu, cara membaca kita menjadi lebih aktif dan lebih mudah menangkap gagasan yang ada.

Read. (1) Membaca adalah langkah ketiga, bukan langkah pertama atau satu-satunya langkah untuk menguasai bacaan; (2) Pada tahap ini 
konsentrasikan pada penguasaan ide pokok serta detail yang penting, yang mendukung ide pokok.

Recite. (1) Setiap selesai membaca suatu bagian, berhentilah sejenak. (2) Cobalah menjawab pertanyaan-pertanyaan bagian itu dan menyebutkan hal-hal penting dari bab itu; (3) Buatlah catatan seperlunya; (4) Jika masih kesulitan, ulangi membaca bab itu sekali lagi

Review. (1) Setelah selesai membaca, telusuri kembali judul, subjudul, dan bagian-bagian penting lainnya; (2) Tahap ini selain membantu daya ingat dan memperjelas pemahaman juga mendapatkan hal-hal penting dari bacaan tersebut.

\section{SIMPULAN DAN SARAN Simpulan}

Dalam pembelajaran membaca melibatkan siswa untuk aktif dengan bimbingan guru, agar konsep yang ada pada pokok bahasan tersebut dapat dipahami, sehingga dapat meningkatkan keterampilan membaca siswa. Dengan peningkatan keterampilan membaca menggunakan metode pembelajaran SQ3R, diharapkan siswa mampu memecahkan masalah, mengambil keputusan, berfikir kritis, dan berfikir kreatif sehingga hasil belajar siswa dapat juga ditingkatkan. Metode SQ3R ini diharapkan siswa dapat memahami dan mengingat materi dalam jangka waktu yang lebih lama/bersifat permanen. Penggunaan metode SQ3R dalam pembelajaran akan terasa lebih menarik sehingga dapat meningkatkan motivasi untuk memahami suatu bacaan.

\section{Saran}

Seharusnya metode SQ3R selain diarahkan kepada kepentingan pembaca sebagai pribadi, juga diarahkan kepada suatu metode pengajaran pembaca untuk kepentingan orang lain. Metode SQ3R ini diharapkan siswa dapat memahami dan mengingat materi dalam jangka waktu yang lebih lama/bersifat permanen. Tingkatkanlah keterampilan membaca menggunakan metode pembelajaran SQ3R, siswa mampu memadukan kemampuan motorik dengan kemampuan kognitif serta diperlukan waktu yang relatif singkat guna memperoleh informasi yang ada dalam bacaan menggunakan metode SQ3R dalam pembelajaran akan terasa lebih menarik sehinggadapat meningkatkan motivasi untuk memahami suatu bacaan.

\section{DAFTAR PUSTAKA}

http://kafeilmu.com/tema/ membaca-kritis-untukmenulis.html

Penuntun Belajar di Perguruan Tinggi. Medan: Unimed

Sigalingging, H.2011. Teori dan Praktik dalam Pengajaran Membaca. Medan: Unimed Simaremare, R.2011. Membaca. Medan: Unimed Tarigan, Henry Guntur.2005. Membaca Sebagai Suatu Keterampilan Berbahasa. Bandung: Angkasa Bandung 